\title{
FILOSOFINĖS TOTALITARIZMO ANTINOMIJOS
}

\author{
Lilijana Astra \\ Mykolo Romerio universiteto Filosofijos ir humanistikos institutas \\ Ateities g. 20, LT-08303 Vilnius, Lietuva \\ Telefonas (+370 5) 2714628 \\ Elektroninis paštas lilijana@mruni.eu \\ Virginija Jakimenko \\ Mykolo Romerio universiteto Filosofijos ir humanistikos institutas \\ Ateities g. 20, LT-08303 Vilnius, Lietuva \\ Telefonas \\ Elektroninis paštasvijak@mruni.eu \\ Pateikta 2015 m. gruodžio 15 d.; parengta spausdinti 2015 m. gruodžio 30 d.
}

DOI:10.13165/SMS-15-7-2-02

Santrauka. Politinio totalitarizmo fenomenu tyrimo objektai implikuoja naujas teorines tyrimo prieigas. Straipsnyje analizuojama antinomiška (prieštaringa) arba destrukcijai pasmerkta bet kurios rüšies politinio totalitarizmo sistemos lemtis kai, atsiradus neišsprendžiamiems vidiniams prieštaravimams tarp istatymų, prigimtiniu žmogaus raidos dèsniu ir principu, ji patiria savaiminị žlugimą.

Iškilaus mastytojo Josifo Levino politinés filosofijos refleksijoje įdèmiai tiriami politinès prievartos reiškiniai, pabrėžiant, kad visiškai priešingu ir nesuderinamu, t. y. antinomišku, žmogiškojo sakralumo ir ikicivilizacinio lygmens žiaurumo savybiu derinys, kuris apibüdina totalitarinès samonès struktūrą.

Reikšminiai žodžiai: refleksija, totalitarizmas, antinomijos (prieštaros), ideologija, vertybès.

Socialinių mokslų studijos / Societal Studies

(c) Mykolo Romerio universitetas, 2015

(C) Mykolas Romeris University, 2015
ISSN 2029-2236 (print), ISSN 2029-2244 (online) http://www.mruni.eu/lt/mokslo_darbai/SMS/ http://www.mruni.eu/en/mokslo_darbai/SMS/ 


\section{Ivadas}

Hannah Arendt, viena iškiliausių praejusio amžiaus politinių mąstytojų, savo klasikine tapusioje studijoje apie totalitarizmo ištakas klausè: „Kas atsitiko?”, „Kodèl tai atsitiko?", „Kaip tai galejo atsitikti?"1.

XX amžiuje ịsitvirtinusio totalitarizmo fenomeno apraiškos tapo istoriškai naujais diktatūrinio valdymo modeliais, visuotinei politinei kontrolei pajungusiais visas socialinio, ekonominio ir kultūrinio gyvenimo sritis. H. Arendt totalitarinius nacizmo ir stalinizmo fenomenus apibrèžè kaip iš esmès tapačius.

Josifas Levinas², vienas iškiliausių sovietinio laikotarpio mąstytojų, pastebejo: „Mūsų vaikaičiai ir provaikaičiai negalès net ịsivaizduoti, kaip mes galejome gyventi ir išgyventi šitiek metų, kai bet kurią naktị kiekvienam iš mūsų grèsè areštas, sušaudymas arba tremtis ị tokị mirties lagerị, iš kurio nesugrị̌žtama; kai kiekvienas iš mūsų galèjo tapti bet kurio skundiko auka, o budelis būdavo apdovanojamas ištaigingu butu arba vila ir turtu, atimtu iš nukankintos aukos “" .

Josifas Levinas daugelị dešimtmečių ịdèmiai gilinosi ị savo šalies politinès prievartos istoriją, rašydamas naktimis ir „i stalčių“, nes, kaip ir visi, labai bijojo KGB žiaurumų - kūrybiškai mąstančios asmenybès būdavo uždaromos ị beprotnamius arba tremiamos i Sibiro lagerius. Mąstytojas rašè, kad totalitarizmui, arba visoms prievartinèms diktatūroms, būdingos organizuotos žudynès, organizuota apgaulè, organizuotas melas ir organizuota korupcija. Tačiau, norint atskleisti paslaptingą ir nežmonišką jų veikimo galią, būtina ịsigilinti ị jų atsiradimo priežastis.

Apsidrausdamas nuo galimo suemimo, jis ir savo įžymiąją rusiškojo totalitarizmo ištakų studiją pavadino „Pamišèlio užrašais“, nes kaip kitaip sovietmečiu galèjo būti pavadintas politinės prievartos prigimties ir jos istorinių išsigimimų tyrimas. Leviną ypač domino dvi agresyviausios pasaulinès ideologijos; bolševizmas ir nacizmas, kurios ištisą šimtmetị buvo ịgijusios tiesiog titanišką energiją, o jų griaunamoji galia tarsi neregètas geopolitinis taifūnas praūžè per visą Europą ir Aziją.

\section{Rusiškojo totalitarizmo ištakos}

XX amžiuje Rusija kaip totalitarinè valstybė patyrè išskirtinị politinị nuosmuki iki pat ikicivilizacinio lygmens, kuriame atsivèrè nelogiškai žiauraus ir iracionalaus blogio pragarmès, kurias nebuvusiems arba esantiems kitapus sunku net ịvardyti.

1 Arendt, H. 2002. Totalitarizmo ištakos. Vilnius: Tyto alba, p. 22.

2 Josifas Levinas (1901-1984) - unikalios filosofinès lemties mąstytojas, savo metafizinèmis, pažinimo teorijomis, etinèmis, estetinèmis, politinèmis ir religinèmis idejjomis iškilęs ne tik virš savo gyvenamo laikmečio, bet ir virš klasikinès bei moderniosios filosofijos tradicijų. Kalbant apie pasaulèžiūrines J. Levino gyvenimo ištakas, pabrèžtina, kad jų formavimasis sutapo su globaliais epochos ịvykiais, kuriuos sukèlè Pirmasis pasaulinis karas ir imperinès Rusijos žlugimo agonija, prasidèjęs bolševikų teroras. 
Apie jas liudijęs Varlamas Šalamovas pastebi, jog kančios neišaukština žmogaus, kaip apie tai bylojo klasikinè humanistinè tradicija ir pasaulinė literatūra. Sukrečiančiuose Kolymos pasakojimuose jis aprašo šiurpią milžiniškų Sibiro mirties lagerių kasdienybę, kurioje totalinès politinès savivalès nužemintas ir pasmerktas žmogus yra žalojamas, bukinamas, netikètai atsiveriant naujam budelio ir jo aukos vaidmeniui - jie abu pasirengę pasikeisti vietomis. ${ }^{4}$

Mąstydamas apie istorines politines prievartos fenomeno bruožus, Josifas Levinas pabrèžia, kad tik visiškai priešingų, netgi poliarinių sakralumo ir žveriškumo bruožų derinys apibūdina būtent rusiškosios totalitarinès sąmonès struktūrą. Pavyzdžiui, Rasputino asmenyje kaip siaubingame groteske neatskiriamai susiliejo, susipyné ir šventumo ir gyvuliškumo (žveriškumo) pradai. Taigi, jei Europoje šimtmečių laikotarpiu humanizmo idejos tik stiprejo, tai Rusijoje ši prieštaringa viduramžiškos sąmonès struktūra išliko žymiai ilgiau, humanizmo idejos taip ir neįsitvirtino, o „šventumas“ tapo galutinai suardytas bolševikmečiu.

Totalios politinés prievartos istorija nèra atsitiktinių ívykių kratinys, o naujasis totalitarizmas nebūtinai turi būti panašus ị senąjị. Josifo Levino politinès filosofijos refleksijoje būtent rusiškosios filosofinès tradicijos menkumas fatališkai ir negrižžtamai paveikè visos valstybės raidą arba istorinę lemtị: né kiek ne mažiau nei ilgaamžis totorių jungas šią milžinišką šalį izoliavęs nuo vakarietiško mąstymo ir tikejjimo. Jis rašo: „Rusijoje filosofinè mintis snaudè. Rusija dar neturèjo savo iškilių mąstytojų, nesukūrè savosios filosofinès mokyklos, kuri būtų paženklinusi pirmapradę visos nacijos sanklodą, panašiai kaip kartezietiškumas ir rusoizmas Prancūzijoje, empirizmas - Anglijoje, klasikinis idealizmas Vokietijoje. Nebuvo nieko panašaus net ị scholastinę mokyklą, atsiradusią europietiškaisiais Viduramžiais". Taigi, ị Rusiją filosofija taip ir neatẻjo, o jos minties, buvusios rimties arba miego būsenos taip ir nepažadino. Josifo Levino nuomone, stačiatikybė monopolizavo visas (arba visas bent kiek svarbesnes) kultūrinio gyvenimo sritis, nepalikdama vietos savarankiškam filosofiniam mąstymui. Ir tai negalëjo nepalikti ryškios žymės rusų inteligentijos kritinei savirefleksijai ateityje. Rusijoje filosofinė mintis visuomet buvo religijos arba politikos tarnaite, kuri niekada nebuvo vertinama kaip visaverte ir jos buvo lengvai atsisakyta, kai pirmoji buvo uždrausta, o antroji - išmesta iš visuomenès gyvenimo sferos, ịsigalejjus totalitarinei diktatūrai. Taigi, Rusija - vienintelè didelè valstybė Europoje, savo formavimosi metais neturejusi išplètoto filosofinio mąstymo, lygiai kaip ir klasikinio gerovès laikotarpio.

Josifas Levinas pastebi, kad visa senosios Rusios gyvenimo sankloda ir ne vien senosios, galbūt, būtų buvusi visiškai kitokia, jei tik rusų vienuolynuose būtų buvę mokoma ir rašoma, kaip kad vakarietiškuose vienuolynuose - lotyniškai, graikiškai ir jei prie viso to dar būtų studijuojamas Platonas ir Aristotelis. Jau žymiai vèliau, totalitarinejje sovietų sistemoje, filosofija kaip tik ir tapo pirmąja įsigalinčios 
totalitarinès politinès sistemos auka (nekalbant apie politinę literatūrą); kurị laiką gyvavo tik periferiniai filosofijos skyriai: estetika, filosofinè psichologija bei jų raiškos židiniai. Šie didžiojo lūžio metai žemès ūkyje taip pat tapo totalios prievartinès kolektyvizacijos pradžia ir kartu visų mąstymo sferų pabaiga. ${ }^{6}$

Beje, Josifo Levino nuomone, Rusija nepergyveno ir autentiškos politinès revoliucijos. Caro vienvaldystė „ištįso” iki tokio laikmečio, kuriame išryškèjo kaip niekad sudètingos socialinès problemos, o jų atsiradimą sąlygojo ne tik atsilikusio feodalinio gyvenimo atgyvenos, bet ir užgimęs kapitalizmas. Todèl margaspalvé, iš ịvairių sluoksnių kilusi rusų inteligentija taip ir nespejo subrandinti savarankiškos, pasitikinčio ir politiškai nepriklausomo kritinio mąstymo ir nacionalinès savimonès.

Josifas Levinas ironiškai pastebi, kad rusiškas protas iš viso linkęs ị kraštutinumus tiek ị dvasingumą, tiek ir ị materializmą, taip nukrypdamas (arba pasiduodamas) ¡ žeminančią apgaulę. Bet ir vienu, ir kitu atveju jis linkęs pajungti protą tikejimui, o tikejimą - valiai. Wishful thinking yra sustiprinamas wishful belief: taip ir vienas žymiausių rusų filosofų Nikolajus Berdiajevas buvo įsitikinęs, kad Paskutiniojo Teismo dieną, visiems prisikeliant iš mirusiųjų, prisikels ir jo mylimas katinas. Josifas Levinas teoriškai apibendrina: savosios klasikinès filosofinès mokyklos neturëjimas, kuri, viena vertus, būtų drausminusi, kita vertus - gilinusi kritinị filosofinị mąstymą, tapo pražūtingu rusų politinès valdžios perspektyvai. Nors rusų inteligentija godžiai studijavo ịvairias Vakarų filosofijos kryptis, tačiau iš karto pradèdavo jas dogmatizuoti ir kanonizuoti. Toks likimas ištiko ir Markso mokymą, kuris tuo metu labiausiai atitiko vyraujančias socialines ir etines nuotaikas ir kartu suteike joms mokslinį paaiškinimą bei pateisinimą. Jei prancūzai ir anglai, išauklèti racionalizmo ir empirizmo dvasioje, marksizmą vertino kaip pernelyg metafizinį, nepakankamai racionalų arba empiriškai pagrịstą, o vokiečiai, išauklèti klasikiniame idealizme - nepakankamai metafizinị ir giliamintị, tai Rusijoje panaši filosofinè prieštara net neegzistavo

Taigi, viso to rezultatas - rusiškojo filosofinio mąstymo slydimas paviršiumi, neturinčiame nei deramo racionalaus, loginio, nei empirinio pamato.

Štai šiame kontekste, Josifo Levino įsitikinimu, ir atsiranda svarbiausioji Spalio revoliucijos antinomija. Valstybe ir revoliucija - tai du tarpusavyje nesuderinami reiškiniai. Vienas iš jų naikina, žudo kitą. Semantinè totalitarizmo antinomija (gr. anti "prieš“ + nomos „̦statymas“) - tai prieštaringas politinis reiškinys arba politinio proceso prieštaravimas pačiam sau; prieštaravimas tarp dviejų logiškai interpretuojamų ir pagrịstų reiškinių, kurių teisingumo arba melo negalima paaiškinti totalitarizmo paradigmos kriterijais.

Laisvé, lygybè, gerové - visos šios pamatinès vertybès Stalinui buvo tapusios neesminiais dalykais. Taip ir susiformavo visuomenė, kurioje milijonams žmonių buvo atimta jų asmeninè laisvé, alinant juos nepakeliamu darbu lageriuose; šioje pavergtoje visuomenèje nekontroliuojamai įsiviešpatavo biurokratija, o milijonai 
žmonių mirè iš bado, kentė didžiausią skurdą, valgè žolę, gyveno ankštai susispietę net po 10 žmonių viename kambaryje - tokia visuomenè buvo pavadinta socialistine.

Pažymėtina, kad politinio totalitarizmo schemoje išnyko netgi toks paradoksalus reiškinys, kai visiškai nemąstantis ir netgi nekritiškai vertinantis absoliučiai visus, netgi prieštaringiausius savo viršininkų nurodymus, žmogus staiga tampa pačiu vertingiausiu kapitalu ir labai patogia naujosios visuomenès - ne tik socializmo, bet ir komunizmo statybine medžiaga.

Juk niekas negalejjo net ịsivaizduoti, kad dujų kamerose galima numarinti 5-6 milijonus žmonių, lygiai kaip niekam nè ị galvą neatejjo mintis, kad galima ir net bus ịgyvendinama prievartinė $120 \mathrm{mln}$. valstiečių kolektyvizacija, o milijonai žmonių kalès nepakeliamai sunkaus prievartinio darbo lageriuose bei vyks visi kiti stalininio laikmečio žiaurumai.

Mąstytojas teigè: „Aš netikiu vergiška prigimtimi.“" Jo ịsitikinimu, jei žmogus net gimsta nelaisveje, tai kaip ir kiekvienas gyvas padaras jis gimsta jau būdamas laisvas ir turèdamas giliausią laisvès poreikị visiems tiems žmogiškosios raiškos veiksmams, ị kuriuos ji pastūmejja kritinis mąstymas ir tiesos pažinimo siekis. Taip išryškẻja antinomiška bet kurios rūšies politinio totalitarizmo sistemos lemtis, kai, atsiradus neišsprendžiamiems vidiniams prieštaravimams tarp įstatymų, prigimtinių žmogaus raidos dèsnių ir principų, ji patiria savaiminę destrukciją ir žlugimą.

\section{Išvados}

1. Politinio totalitarizmo sistema igalina apibréžti valdžios diegiamų ideologinių dogmų ir viešojo socialinio, kultūrinio gyvenimo bei asmens laisvès kontrolès ribas.

2. Politinè valdžia ịgyja ne tik absoliučią vykdomąją galią, bet ir neribotas galimybes ją taikyti. Totaliam žmogaus pajungimui reikalingas valstybinès prievartos aparatas lygiai kaip neformalus teroras ir savivalè.

3. Mąstytojas Josifas Levinas sukūrẻ vieną ryškiausių XX amžiaus rusiškos totalitarinès sistemos atsiradimo, ịsigalejimo ir griūties sampratą, pagrindęs antinomišką jos prigimties pobūdị. Kitaip tariant, jis išplètė klasikinio kantiškojo antinomijos supratimo ribas, kai teorinis protas (vok. Vernunft) prieštarauja pats sau.

4. Leviniškoji semantine totalitarizmo antinomija - tai vidinis politinio reiškinio arba proceso prieštaravimas pačiam sau; prieštaravimas tarp dviejų logiškai interpretuojamų ir pagrịstų politinių reiškinių, kurių teisingumo arba melo negalima paaiškinti totalitarizmo paradigmos rémuose. Josifas Levinas, mąstydamas apie istorinius politinius prievartos fenomeno savitumus, pabrèžia visiškai priešingų, netgi poliarinių sakralumo ir žvėriš- 
kumo požymio derinị, kuris apibūdina rusiškosios totalitarinès sąmonès struktūrą.

5. Jo manymu, Rusijoje filosofinè mintis niekada nebuvo vertinama kaip savarankiška ir jos buvo lengvai atsisakyta, kai pirmoji buvo uždrausta, o antroji - išmesta iš visuomenès gyvenimo sferos. Rusiškos totalitarinès valdžios pobūdį ir anomiškumą sąlygojo savosios klasikinès filosofinès mokyklos neturejjimas, kuri, viena vertus, būtų drausminusi, kita vertus - gilinusi kritini filosofinį mąstymą.

\section{Literatūra}

1. Arendt, H. 2001. Totalitarizmo ištakos, Vilnius: Tyto alba.

2. Levi, I. 1994. Sochinenija. Tom 2. Moskva.
3. Šalamovas, V. 2015. Kolymos pasakojimai. Vilnius: Briedis.

Lilijana Astra, Mykolo Romerio universiteto Filosofijos ir humanistikos instituto lektorè, mokslų daktarè. Mokslinių tyrimų kryptys: šiuolaikinè sąmonės filosofija, vertybių kaita globalioje visuomenèje.

Virginija Jakimenko, Mykolo Romerio universiteto Filosofijos ir humanistikos instituto docentè, mokslų daktarè. Mokslinių tyrimų kryptys: logika, šiuolaikiné filosofija. 


\title{
PHILOSOPHICAL ANTINOMIES OF TOTALITARIANISM
}

\author{
Lilijana Astra, Virginija Jakimenko \\ Mykolas Romeris University, Lithuania
}

Summary. Modern research of such complex political phenomena as totalitarianism requires new concepts and theoretical approaches. Even more they are related with a phenomenon of antinomy and emergence of internal conflicts between the laws of the natural evolution of human laws and principles. Nevertheless totalitarianism undergoes spontaneous destruction and ruin.

A famous thinker Joseph Levin in his conceptual system of political philosophy carefully investigated totalitarianism and the nature of brutality. Totalitarianism is based on antinomies that are diametrically opposed and irreconcilable to humanistic mind and culture.

Keywords: reflection, totalitarianism, antinomy, ideology, values.

Lilijana Astra, Mykolas Romeris University Institute of Philosophy and Humanity, Lecturer, Doctor of Philosophy. Research interests: philosophy of modern consciousness, change of values in global society.

Virginija Jakimenko, Mykolas Romeris University Institute of Philosophy and Humanity, Associated Professor, Doctor of Philosophy. Research interests: logic, modern philosophy. 